\title{
Reflection on Rational Return of English Fever and Teaching Reform of Higher Vocational Flight Attendant English
}

\author{
Changjun Yang \\ Haikou College of Economics, Haikou, 570203, China
}

\begin{abstract}
Keywords: Teaching Reform of higher Vocational Flight Attendant English. Course Design. Teaching Material System. Diversified Education. Multiple Evaluation
\end{abstract}

\begin{abstract}
The discussion of course design reform, teaching material system reconstruction, diversified education implementation, and multiple evaluations is no longer the new topic of teaching reform of higher vocational flight attendant English. However, it is rather necessary to reconsider the reform of above contents especially course design reform under the background of rational consideration of English fever return. This paper puts forward some thoughts on teaching reform of higher vocational flight attendant English and offers references for English teachers in the frontline.
\end{abstract}

\section{Rational reflection on cooling of English fever and College English teaching of colleges and universities}

\section{Reasons for cooling}

National English fever which lasts for 30 years has already been cooled. China Education Daily revealed that the reform planned to carry out socialized more foreign language examinations in one year rather than only unified college entrance examination. People started to ask how on earth the effects are for they have spent so much time and energy in learning English. Please look at the first global English Proficiency Index Report issued by Education First (EF) in 2011. The first country in Asian region is Malaysia which ranks 9 in the world. China ranks 29 and is no match for Korea which ranks 13 and Japan which ranks 14. However, in IELTS test of 2004 and 2005, the average scores of Chinese students are obviously lower than that of the world, and their oral test scores are the last one of the world. Such disappointing results make us to ask what happened to the English teaching in China.

Colleges and universities are the battle position of English teaching in China. We may have to admit that there is a certain kind of unshakable relevance among the social abnormal English fever, poor learning effects, and College English teaching in colleges and universities. But the problem exists in mutual effects and interinfiltration.

\section{How to face the cooling}

In any case, teachers in colleges and universities must face up to the various problems caused by English fever cooling, and consciously inspect and reflect the teaching problems of College English. Supposing that all teachers in colleges and universities can hold a more objective, calm and down-to-earth attitude than other social classes, find out what College English has thought to be perfectly justified is in fact a kind of defect through 30 years' of abnormal English fever and poor learning effects, bring order out of chaos, and firm the steps of reform, it will become the bright prospect of English teaching in China.

We, who have engaged in higher vocational flight attendant English teaching for so many years, hope to combine present social reflection on English learning fever, make use of its positive energy, and analyze the College English teaching problems of higher vocational flight attendant major with rational thinking perspective. We are looking forward to negating in affirmation, speculating in negation, and finding out a sound development path for the teaching reform of higher vocational flight attendant English. 


\section{Correctly position College English of higher vocational flight attendant major and don't need to blindly follow the way of reducing class hours or turning compulsory courses into elective ones}

Recently, the "reform program of college entrance examination" issued intensely in multiple areas all started with English, which aroused questions of "Chinese English teaching with large amounts of resources but poor effects" of all walks of life again. Some undergraduate universities cannot stand these questions, put forward that students only need to learn College English for one year, and allow students to take extended English courses like communicative English, IELTS, TOEFL, etc as elective courses. As for this, someone in higher vocational colleges has put forward that local undergraduate universities open College English for one year as a compulsory course and higher vocational colleges merely need to open it as an elective course. Even though College English is opened as a compulsory course, the teaching hours should be reduced.

Opinions dominated by public opinions and lack of argument should be treated carefully. Taking "The undergraduate universities have lowered requirements, how can higher vocational colleges do?" as a basis of following suit, we think it is irrational and extreme opinion. The documents of education ministry clearly defined that undergraduate education and higher vocational education are different with each other merely in the aspect of classification rather than level. Therefore, higher vocational colleges shouldn't blindly follow the trend just because of what undergraduate universities have done. There is no doubt that College English in higher vocational colleges should accordingly conduct reform, but the problem of how to reform should accord with market's different requirements for students of different majors. Indeed, the College English of some certain majors can be opened as an elective course; some should be opened as a compulsory course; some should not only be opened as a compulsory course but also need further reform and talent cultivation quality concept of higher level. We think higher vocational flight attendant major belongs to the latter. This opinion is decided by employment market and industrial needs rather than personal willingness.

\section{The first reform way of higher vocational flight attendant major's College English: reforming original course design of College English and rebuilding teaching material system}

For years, College English teaching in colleges and universities has become highly homogenized. Similar course design, teaching material, teaching mode and evaluation mode constantly submerged students' individuality and creativity. Even the teachers are not able to struggle out of this kind of vortex. It is not only a kind of helplessness but also a kind of crisis. Therefore, reform is imperative. How to adjust measures to local conditions, avoid homogenization, and form own unique style and training standard of professional are the projects we are striving to explore.

Basing on the above opinions, we must place course design reform at the first place of College English reform of higher vocational flight attendant major. Our understanding is that course is the subject teaching plan built by colleges in accordance with a certain kind of training target. It is the most direct way of realizing training target and the core factor of influencing education quality. The final effects of any form of education are decided by the course design and implementation process faced by students.

Building "integrated" course design which organically combines general English and English for special purpose, and reforming defective “double-section” course design

1). Most higher vocational colleges divide higher vocational flight attendant English into two sections for teaching namely "general English" and "English for special purpose". "General English" mostly adopts College English-Integrated Course the contents of which are mainly language and literature with relatively strong enjoyment and plot (some colleges also add Learning to Speak: An English Video Course and so on). It aims to further enrich students' language knowledge and at the same time train and improve students' English ability of listening, speaking, reading, writing, and translating. "English for special purpose” highlights contents' practicability and pertinence, aiming to realize the practicability of higher vocational education from the perspective of major and targeted 
position. Therefore, most colleges adopt English for Civil Aviation Cabin Service or Flight Attendant Oral English to make students learn and grasp professional English for future employment position.

Different tasks of "general English" and "English for special purpose" naturally extend a double-section teaching thought of "reinforcing general English first and then studying English for specific purpose”. The separated "double-section" course design of "general English" and "English for special purpose" can be accepted by majority of higher vocational colleges, showing that its existence has certain rationality. Generally, general English is arranged during 1-3 semester while English for specific purpose during 3-4 or 4-5 semesters (there are differences among colleges). We tentatively call this kind of teaching arrangement as "double-section” course design.

If placing “double-section” course design under the rational thought view of English learning fever return, we can find that such kind of Chinese course design isn't suitable for higher vocational college reality. It is merely the inertial continuation in higher vocational education of "enhancing the foundation and widening the specification" traditional conception in undergraduate education, inconsistent with higher vocational education's requirement of practicability. If higher vocational education system is designed in accordance with "double-section" course design, students should spend almost 4 semesters to learn general English. Obviously there exist problems of long existing time, too many occupation hours and occupying professional practical courses' hours. It is more unreasonable that long-term general English learning isn't able to integrate with English for specific purpose needed by future occupation, and lengthening students' conversion process from learning English to using English isn't beneficial to maintain students' learning initiative.

2). There are lots of discussions in foreign language teaching field concerning course design. Zhang Jie (2005) put forward "College public English and professional English from separation to integration, namely professionalization of public English teaching and publicization of professional English teaching”. His opinion played a certain role in educational circle. Xie Huali (2012) proposed even more specifically "Taking general English as trunk and professional English as branch to develop English teaching, embodying the industrial features of higher vocational education in English teaching, combining occupations to cultivate students' English application ability, and realizing the dynamic integration of specialized knowledge and English language form". Her view is more suitable for the basic principle of higher vocational education "Taking practicality as focus, sufficiency as limitation and application as target”. We call dynamic integration of general English and professional English in this paper "integrated" course design.

\section{Rebuilding teaching material system is the basic condition for changing "double-section" and carrying out "integrated" course design mode}

1). In linguistic system, the generality of "general English" and "English for special purpose" is greater than their individuality all along. Their contents, forms, and teaching method application in fact integrate with each other organically. However, integrating the specialized vocabulary, civil aviation knowledge, idiomatic usage, cultural custom, immersive occupational scene, and authentic passenger cabin expression of flight attendant occupation into learning at all stages as early as possible will inevitably offer students more occupation English training than "double-section" teaching material.

2). New teaching material system doesn't mean writing a heap of teaching materials but adding "integrated" new concept of the organic integration of general English and professional English while writing teaching materials.

As for the teaching material serving “double-section”, students have to learn College English-Integrated Course, Learning to Speak: An English Video Course, Basic Spoken English, etc at the stage of "general English" but also have to study Flight Attendant Oral English at the stage of "English for special purpose”. Such kind of design lays heavy burdens on students and the effects may not be as good as expected.

New teaching material in accordance with "integrated" new conception is able to integrate above contents into Civil Aviation Flight Attendant English Tutorial of 1-4 volumes. Students study one volume for each semester and won't study other teaching material after finishing all the volumes, which relieves the burden of both teaching and learning. At the same time, it embodies the integrity of 
language teaching better, considers the English basis reality of higher vocational students, and gets close to the cultivating orientation of practical talents of higher vocational education.

3). Civil Aviation Flight Attendant English Tutorial will be designed according to Education Ministry’s Fundamental Requirements for English Course in Higher Vocational and Three-year Colleges and actual operational requirement of flight attendants. It takes "Action-oriented and Task-driven" as main teaching mode and penetrates "Teaching, learning and acting” all through the process.

The second reform way of higher vocational flight attendant major's College English: carrying out diversified teaching and multi-layered training objective and teaching requirement

Rational reflection on English learning in colleges and universities forces us to admit a fact that in recent years, there are great differences among students' English basis level, cognitive competence, learning motivation, and psychological quality with the continuous expansion of higher vocational education scale and increasingly declining of higher vocational students' quality. Therefore, emphasizing generality and average development is unrealistic. We should carry out diversified teaching, stratified teaching and classified instruction among higher vocational students.

1). Stratified teaching and classified instruction are setting different levels of learning objectives for students of different levels, carrying out different levels of teaching and management, organizing different levels of tests, and making students at all levels achieve full development on their own basis in accordance with the basic requirement of professional cultivation target and teaching programme.

The division of students can be in accordance with the results of exams after the beginning of semester and students' willingness. The division should also be dynamically managed in order to fully arouse students' positivity.

2). New teaching material Civil Aviation Flight Attendant English Tutorial written in accordance with "integrated" mode also takes the requirement of "stratified teaching and classified instruction" into consideration. Reading Text, Listening In, Speaking Out, and Applied Writing we have planned all have $\mathrm{A}$ and $\mathrm{B}$ parts. Part $\mathrm{B}$ belongs to extended training which has no teaching requirement for students with relatively poor basis.

The third reform way of higher vocational flight attendant major's College English: promoting reform of teaching and learning process with multiple evaluations formed by combination of formative evaluation and terminative assessment

In the teaching process of flight attendant major's College English, we should accord with the teaching requirement and target of higher vocational courses, combine features of teaching mode, make sure evaluation contents and method, integrate formative evaluation and terminative assessment requirement, embody the diversification of evaluation subject, evaluation form, evaluation content, and evaluation standard, and strive to promote teaching and learning process reform with multiple evaluation.

\section{Conclusion}

In colleges and universities, the phenomenon that English education effects and devoted time and energy are inappropriate is relatively severe. English teachers should be responsible to conduct profound reflection on Chinese English teaching which has consumed large amounts of resources. Concerning reforming course design, rebuilding teaching material system, and carrying out diversified teaching and multiple evaluations, this paper puts forward some directive reform opinions for higher vocational flight attendant major's College English. It aims to provide some reference value for reform of highly homogenized College English teaching in colleges and universities, similar course design, teaching material, teaching mode and evaluation method. 


\section{Acknowledgments}

This paper is the phasic research achievement of college key funding project of education research and education reform named "Innovation research and practice of public English teaching mode on basis of students' application ability and occupational quality training---Taking junior college level of flight attendant major as an experimental unit”. Project director: Yang Changjun. (Project number: hjyj2012002Z)

\section{References}

[1] Zhang Jie: Professionalization of public English teaching and publicization of professional English teaching---the only way of colleges and universities' English teaching reform in China, Foreign Languages and Their Teaching,2005.11

[2] Xie Huali: Analysis on the only way of higher vocational colleges' English teaching reform in China, Career Horizon, 2012.4

[3] Zhang Bomin, \&Yang Changjun: A primary exploration on constructing higher vocational college English course evaluation system of multiple evaluation, Journal of Hainan Radio and TV University, 2009.1 